\title{
On the Coordination between International Trade and International Logistics under the Strategy of "Belt and Road Initiative" Ye Peng
}

\author{
Jiangxi Vocational Technical College Of Industry \& Trade, Jiangxi, Nanchang, 330038
}

key words One Belt and One Road; International Logistics; International Trade Relations

\begin{abstract}
The "One Belt and One Road" strategy is an overall strategic implementation by the collection of information technology, international trade cooperation, transportation industry and so on. The cooperative relationship between international trade and logistics brings vitality to the "One Belt and One Road" of our country and injects new blood among the countries, and also speeds up the business development scope of the international enterprise, changes and innovates the business model and concept of the enterprise, and promotes the national economic development of the national economy. The opportunity of the market.
\end{abstract}

\section{International Logistics and International Trade}

\subsection{Definition of international logistics}

The international logistics is the inevitable trend of the time of the time, it is the collection of different logistics companies distributed around the world, and with the background of the high-speed development of the international trade economy, the international logistics gradually becomes the model of the international first-choice economic transaction. It is the exchange of goods between two or more countries. the international logistics is composed of the technical staff of the logistics, the logistics equipment, the goods trading scheme and the like, and through the international logistics, the economic exchange relationship between the state and the state can be obtained, and therefore, the basis of the international economic trade is the international logistics, It does not only accelerate the operation of the international economic and trade, but also the international trade Yi's countries have helped and supported them in terms of technical and trade difficulties.

\section{2 relationship between international logistics and trade}

The exchange of international economy and trade is becoming more and more frequent, and the importance of international logistics is becoming more and more prominent. International trade has led to international logistics, and international logistics can support international trade very well, which can complement each other. That being the case, countries in international trade do not use international logistics, so economic trade is difficult to achieve, which is a matter of modern international trade. The international trade exchanges are frequent and the demand increases naturally, which makes the international logistics need to increase the transportation efficiency, improve the traffic volume and so on, so as to promote the international logistics companies to be more systematic and perfect in the system and operation mode.

\subsubsection{International trade breeds international logistics}

International trade countries from a few to the majority, international trade goods from scratch, so that international logistics in the soil of international economic trade wanton growth, received a large amount of income, resulting in international trade is becoming more and more standardized, in terms of the size of logistics companies, and transport volume can increasingly meet the requirements of international trade,. In addition to the extensive use of computers, it combines with international logistics, efficiently grasps the information of logistics transportation, and can provide business logistics information through information technology, with a customer and their own convenience, and each single logistics can save logistics information, computer information technology optimized logistics companies. Through the mastery of logistics information 
technology, the scheme of protecting logistics can be worked out, so as to avoid the problems in the process of re-logistics can be found easily and quickly. Of course, with the rapid development of international logistics today, natural international economy and trade are behind the scenes, and the economic benefits it brings far outweigh the economic benefits created by international logistics itself.

\section{The Problems of International Trade and International Logistics}

\section{1 lack of understanding of "Belt and Road Initiative" strategic consciousness}

During his visit to the east of Central Asia and Southeast Asia in 2013, President Xi Jinping, a Chinese state, cautiously put forward the strategic policy of "Belt and Road Initiative", which received extensive attention from the international media. Although "Belt and Road Initiative" was put forward by our country, China's specific implementation plan is not mature enough, including the implementation of projects, specific operations, and so on, which contain many uncertain factors. China is still in the stage of exploring Belt and Road Initiative and does not have the mature technology to master the overall situation. Secondly, the implementation of "Belt and Road Initiative" strategy will also bring a lot of international political problems, which involves the culture between different countries, but also Some countries oppose political problems such as common economy, nationalism and so on. They refuse to share the economy with others for the sake of their own interests. Therefore, there is a great deviation in understanding the strategy of "Belt and Road Initiative" put forward by China, which hinders the implementation of "Belt and Road Initiative".

\subsection{Unsafe international investment and operation hidden danger}

The development of enterprises and the development of international trade can not be separated from a stable business environment. However, as far as the current global security situation is concerned, it is relatively serious. The volatile security situation in some countries, as well as the complex and changeable surrounding situation, are deeply restricting international trade. This complex trade exchange environment also restricts the implementation and development of Belt and Road Initiative strategy in China. It has deeply hindered the overseas investment and operation of our country. This is a huge unstable security hazard faced by international trade and international logistics.

\subsection{The secondary difficulty of international trade and logistics is increased}

The "Belt and Road Initiative" strategy involves a very wide area, some remote areas or terrain has become difficult to transport, its logistics and transportation is extremely inconvenient, not only the natural environment of the region is bad, but also the weather hinders the region. There are great political and cultural differences between international trading countries, which leads to the hindrance of economic exchanges between countries. How to formulate effective international economic and trade is a modern problem. Therefore, the contradiction between international trade and international logistics is also widening. The problems of economic logistics and transportation among countries emerge in endlessly. Cultural differences, economic differences and so on are all the obstacles to the implementation of the "Belt and Road Initiative" strategy. A stepping stone.

\section{4 the development of logistics enterprises is constrained}

When the strategy of "Belt and Road Initiative" was put forward, the major logistics companies saw the market opportunities, but their existing logistics technology was difficult to support the needs of international trade. They only saw the market opportunities but did not realize the prospects for the development of the company, only concerned about the immediate interests. However, how to achieve the connection between countries in international trade is a test for modern logistics companies, but many domestic logistics companies are not aware of this. This also restricts the development of logistics in our country. 


\section{To enhance the complementary relationship between international trade and logistics under the background of the "One Belt and One Road"}

\subsection{Improve strategic awareness and cooperation.}

In the face of nationalized economy, the development and prosperity of international trade has become an inevitable trend, so the country should make use of modern technology to establish a network covering the whole world, involve "Belt and Road Initiative" countries and regions, and promote economic and trade in a harmonious way through effective exchanges. Reach the concept of seeking common ground while reserving differences in political culture. The state needs to reduce the political restrictions on logistics companies, encourage companies to expand foreign trade, increase cooperation with logistics companies, expand the degree of openness to regional economic and trade, establish a network of contacts between companies' trade, promote their exchanges and efficient economic benefits. At the same time, many optimized and excellent systems have been established. And policy, also need to control the trade market scientifically and reasonably, can not only look at "money", ignore fairness, disrupt the market economy order. In order to ensure the reasonable trade of domestic companies, it also improves the position and prestige of Chinese enterprises in the international market.

\section{2 strive to seize development opportunities and ensure trade security}

Obviously, as an important synergy, international trade and international logistics must develop together. Only when the two work together and promote together can major development be achieved. At the same time, the stability of development also depends on the stability of the trade environment. At the same time, we should try our best to maintain the security of trade, actively and reasonably evaluate the rationality and inferiority of trade, and ensure the security and long-term development of trade. To a certain extent, the peace of trade also determines the stable diplomatic relations of neighboring countries.

\section{3 create an environment for international trade and international logistics}

International trade and international logistics are already two closely related fields. Countries need to coordinate and common policies for reasonable arrangements for trade between countries, reduce trade obstacles, especially customs issues, create smooth trading channels, trading companies should also cooperate in good faith, strictly control logistics products, logistics handover can also provide a variety of ways. In this way, the optimal handover scheme can be selected in different environments to ensure the smooth and high-speed logistics channel, and to reduce the time cost, which also optimizes the trading environment. International logistics companies should also build a comprehensive logistics information management system to ensure that businesses and buyers can obtain the required logistics letters. Interest, at the same time, it is also a manifestation of commercial integrity, but also through logistics information management, accelerate the flow of logistics. Under the new policies of various countries, we should create a new environment and achieve a new harmonious and win-win situation.

\section{Conclusion:}

International logistics and international trade have formed an inextricable new situation, the two promote each other, harmonious growth. This is the inevitable trend of the pace of the times, and their relationship is getting closer and closer. Improving the efficiency of international logistics is also speeding up the pace of international economy and trade, and the broader the win-win situation is. Therefore, the countries in international trade need to expand the ideology of opening to the outside world, so as to make new contributions to the better tomorrow of world economic development and benefit the world. 


\section{References :}

[1] Rong Mei. Impact of unit logistics cost on international trade in China: an empirical analysis based on trade gravity model [J]. Commercial economy, 2011 (1).

[2] Sun Lin. How to seize the opportunity of Belt and Road Initiative: improve their competitiveness and integrate into the international logistics [J]. Modern Logistics News, 2014 (9).

[3] Zhu Yue, Cao Lei. Countermeasures to promote the Development of International Trade Logistics in China [J]. Chinese Foreign Investment, 2013 (7).

[4] Xinmanyu. Research on the Construction of International Logistics under the "One Belt and One Road" Strategy[J]. Logistics Technology,2015 (16).

[5] Chen Yao. The Core Connotation and Advance Thinking of "Belt and Road" Strategy [J]. China Development Watch,2015(1).

[6] Mr. Shen, Mr. Xiao Jin. The state-to-state region is in the form of a new shape with my country's "One Belt and One Road" cooperation strategy[J]. Macroeconomic research,2014 (11). 